\title{
The Effect of Dictogloss on Listening Comprehension: Focus on Metacognitive Strategies and Gender
}

\author{
Mina Taheri, Saeed Taki* \\ English Department, Shahreza Branch, Islamic Azad University, Iran
}

Corresponding Author: Saeed Taki, E-mail: taki@iaush.ac.ir

\section{ARTICLE INFO}

\section{Article history}

Received: May 05, 2017

Accepted: July 14, 2017

Published: December 01, 2017

Volume: 6 Issue: 7

Special Issue on Language \& Literature Advance access: September 2017

Conflicts of interest: Non

Funding: None

\begin{abstract}
This study aimed at investigating the effect of dictogloss on EFL learners' listening comprehension as well as on their use of metacognitive listening strategies with a focus on the effects on male and female learners. To this end, a total number of 50 female and male Iranian EFL learners, aged between 12 and 15 years old, at the intermediate proficiency level in a private language school in Iran were selected and randomly assigned to experimental and control groups with 25 male and female learners in each group. Dictogloss was employed to teach the learners in the experimental group for an instruction period of 12 sessions. Participants' listening comprehension was determined through a pre/posttest which was adapted from the listening section of the standard test of PET and their use of metacognitive listening strategies via the MALQ, a questionnaire developed by Vandergrift et al. (2006). The data obtained were submitted to the t-test and results revealed significant improvement in the experimental group's listening comprehension with no significant difference between male and female learners. Finally, the results showed that the listeners in the experimental group made noticeable gains in their choice of metacognitive strategies through using the dictogloss technique. Findings are discussed in light of recent theories of language learning and teaching.
\end{abstract}

Key words: Communicative Language Teaching, Dictogloss, Metacognitive Strategy, Listening Comprehension

\section{INTRODUCTION}

From among language skills, developing the listening skill is often taken for granted. It has received only minimal treatment in the teaching of English as a foreign language (EFL) (Field, 2008; Macaro, Graham, \& Vanderplank, 2007; Vandergrift, 2007; Vandergrift \& Goh, 2011). However, it remains one of the most important skills in language learning (Clement, 2007; Oxford, 1993; Rubin, 1994). In an EFL context, listening is the first encounter with the target language (Berne, 2004) and the first step towards fully acquiring a second language (Liu, 2009). However, in spite of the importance of developing listening comprehension abilities, L2 learners are rarely taught how to listen effectively (Flowerdew \& Miller, 2005; Rost, 2011; Vandergrift \& Goh, 2011).

Recently, in teaching listening the focus of attention has shifted to an emphasis on more communicative approaches such as task-based language teaching (TBLT), which involves interactive listening activities in order to complete a task (Flowerdew \& Miller, 2005; Rost, 2011). Vasiljevic (2010) in her article introduced dictogloss as an interactive method of teaching listening comprehension to L2 learners. Dictogloss, originally developed by Wajnrub and Malay (1990) to teach grammar, when applied to listening, involves four stages: preparation, listening, reconstruction and analy- sis and correction (Vasiljevic, 2010). It embodies important principles of language learning such as learner autonomy and cooperation between learners, which requires the active involvement of students.

There have been new approaches to teaching listening, many of which are informed by recent developments in the field of cognitive psychology (Flowerdew \& Miller, 2005; Goh, 2008; Macaro, Graham, \& Vanderplank, 2007). The metacognitive approach has become especially a more popular research topic (Chamot, 1995; Goh, 2008; Vandergrift, 2004) as learners can be trained to apply effective strategies to cope with the demands of listening (Mendelsohn, 1998).

Dictogloss is assumed to help learners improve perceptual processing of spoken second language input (Wilson, 2003), which is justified on the ground that most teaching approaches to listening emphasize top-down processing and listening for the gist. In other words, listening requires the utilization of both systemic and schematic knowledge (Widdowson, 1983; Buck, 2001). In order to interpret the discourse, the listener must have a sufficient knowledge of the language system (i.e. an understanding of the phonological, syntactic and semantic aspect knowledge) as well as general knowledge of the world. Using dictogloss through specifically designed activities with an emphasis on bottom-up 
processing, dictogloss can greatly help learners develop their listening ability. (Field, 2008). Vasiljevic (2010) also maintains that dictogloss is an interactive method of teaching listening comprehension to L2 learner, which involves several important principles of language learning such as learner autonomy and cooperation between learners.

There have been many studies on the effect of dictogloss on learners' listening comprehension, which all underline the positive role of dictogloss (e.g., Alawiyah, 2016; El-Esery, 2016; Jibir-Daura, 2013; Rismayanti, 2009; Wahjuningsih, 2001; Widiasmara, 2012). On the other hand, research findings confirm that teaching learners metacognitive listening strategies improves listening comprehension (e.g., Al-Alwan, Asassfeh \& Al-Shboul, 2013; Bozorgian, 2012; Coskun, 2010). Hence, considering the merits of raising learners' awareness of metacognitive strategies an also effectiveness of dictogloss the question which remains is whether dictogloss can improve listeners' use of metacognitive strategies. The present study then aimed to find about the effect of dictogloss on listening comprehension and how it could influence listeners' use of metacognitive strategies. The following questions were specifically addressed

1. Does dictogloss have differential effects on the listening comprehension of Iranian male and female EFL learners?

2. Does dictogloss have any significant influence on Iranian EFL learners' choice of metacognitive strategies?

\section{BACKGROUND}

Listening comprehension is a process in which listeners must actively "discriminate between sounds, understand vocabulary and grammatical structures, interpret stress and intonation, retain what was gathered in all of the above, and interpret it within the immediate as well as the larger socio-cultural context of the utterance" (Vandergrift, 1999, p.168). It requires a great deal of mental activity on the part of the listener. Similarly, Rost (2005) asserts that listening includes receptive, constructive, and interpretive aspects of cognition. Further, Caldwell (2008) defines the listening comprehension as an extremely complicated unobservable process which involves simultaneous extraction and construction of meaning through interacting with the oral language.

Formerly, listening was the least emphasized skill in EFL classes; however, it is now recognized as a language skill which needs an active process in the learners' mind and involves a highly complex problem-solving activity (Byrnes, 1984); therefore, it has increasingly received more attention in language learning (Flowerdew \& Miller, 2005; Matheson, Moon \& Winiecki, 2000; Vandergrift, 2004). One way learners can become actively involved in controlling their own learning is through developing certain strategies. "Strategies are specific methods of approaching a problem or task, modes of operation for achieving a particular end, planned designs for controlling and manipulating certain information" (Brown, 1995, p.104).

As related to strategies for listening, O'Malley and Chamot (1990) presented three main types of strategies: cogni- tive, social strategies and metacognitive. Cognitive strategies are related to comprehending and storing input in the working memory or the long-term memory. They include bottom-up strategies and top-down strategies. It is believed that efficient listeners utilize both bottom-up and top-down processing strategies simultaneously (Chiu, 2006; Lu, 2008). Social/affective strategies are defined as the strategies used to collaborate with others, verify understanding or to lower anxiety (Vandergrift, 1999). They are regarded as nonacademic strategies which involve stimulating learning through establishing a level of empathy between the instructor and students (Habte-Gabr, 2006).

Metacognitive strategies are generally concerned with attempts to plan, check, monitor, select, revise, and evaluate, one's own learning. Metacognitive awareness of listening strategies is defined in terms of five factors including problem solving, planning-evaluation, mental translation, person knowledge, and directed attention (Vandergrift, Goh, Mareschal \& Tafaghodtari, 2006). The awareness of listening strategies has been found to be related to language learners' motivation (Vandergrift, 2005), learners' level of education (Rahimi, \& Katal, 2012), technology use for EFL listening (Rahimi \& Katal, 2012), and listening test performance (Zhang \& Liu, 2008).

Based on these promising findings (Cross, 2010; Goh \& Taib, 2006; Vandergrift 2007; Vandergrift \& Tafaghodtari, 2010; Zeng, 2007) scholars urge that metacognitive strategies be a part of instruction in teaching listening comprehension (e.g., Goh, 2008; Vandergrift, 2004). It is assumed that "metacognitive instruction can potentially heighten learners' awareness of their listening and learning processes and develops learners' ability to use appropriate strategies" (Goh, 2008, p.195). Shak (2006) also considers dictogloss as a type of form-focused task which provides a meaning-focused context to raise learners' awareness of the discoursal use of the target linguistic features. However, findings of experimental studies on the effectiveness of metacognitive listening instruction on listening performance are not conclusive and not all research findings corroborate this claim (e.g., Chen \& Haung, 2011; Seo, 2002).

Dictogloss offers several potential advantages for teaching listening comprehension. Nunan (2004) explains that dictogloss is an effective pedagogical task because it is a piece of classroom work that involves learners in comprehending, manipulating, producing or interacting in the target language while their attention is focused on mobilizing their grammatical knowledge in order to convey meaning. According to Nunan (1995), the dictogloss technique provides a useful bridge between bottom-up and top-down understanding. In this study, an attempt was made to investigate the effectiveness of this technique in enhancing learners' awareness of metacognitive listening strategies, which has not been studied in an EFL context.

\section{METHOD}

This study was a quasi-experimental study involving an experimental group together with a control group. The intervention applied to the experimental group comprised a pe- 
riod of instruction using dictogloss as the main pedagogical technique.

\section{Participants}

A total number of 50 female $(\mathrm{N}=25)$ and male $(\mathrm{N}=25)$ learners with an age range between 12 and 15 years old who were studying English as a foreign language at a private language school in Isfahan, Iran were selected for this study. Based on the results of the institute placement test whose reliability and validity were already established, the participants' English proficiency level was identified as intermediate. They were then randomly assigned to two groups, one as the experimental and the other as the control. According to the school register, male and female learners were proportionately distributed in the groups.

\section{Instruments}

There were two instruments used in the study: Preliminary English Test (PET) and Metacognition Awareness Listening Questionnaire (MALQ). PET is an English language test prepared by Cambridge English Language Assessment, which demonstrates an intermediate level qualification to use English for everyday purposes. It is designed to show that learners can use their English language skills in everyday situations when working, studying and travelling. It incorporates all four language skills (Reading, Writing, Listening and Speaking). For the purposes of this study, the listening section was administered to the participants. The listening paper has four parts comprising 25 questions and it takes approximately 35 minutes to complete. Candidates are expected to understand a range of spoken materials, in both informal and neutral settings, on a range of everyday topics. Recorded materials include announcements, interviews and discussions about everyday life.

To find about the participants' use of metacognitive listening strategies, the Metacognition Awareness Listening Questionnaire (MALQ), which was developed by Vandergrift et al. (2006), was given to the experimental group both at the beginning and at the end of the treatment so that possible changes in their use of those strategies could be determined through comparison. The validity of the questionnaire has been explored by the developers using both exploratory and confirmatory analyses by a large sample of different foreign language learners including Iranians (Vandergrift, et al., 2006). The questionnaire contains 21 items; each item is rated on a six point Likert scale ranging from 1(strongly disagree) to 6(strongly agree) without a neutral point so that respondents could not hedge. The MALQ consists of five categories including problem solving (6 items), planning and evaluation (5 items), mental translation (4 items), person knowledge (3 items) and directed attention (4 items).

In order to ensure full understanding, the Persian translation was used in this study. In a pilot study, this version was examined to make sure there would not be any intelligibility problems. The learners' scores were viewed as their metacognitive awareness of the processes and strategies required for successful second language listening comprehension.

\section{Materials}

The texts used for dictogloss included stories selected from learning resources available online. They were checked using the readability formula in order to make sure they were similar and within the readability level that matched the participants' proficiency level. Twelve dictogloss texts were prepared, while parameters such as the topic of each text, their level of difficult, and their length were taken into account.

According to Buck (2001), the length of the texts should not be too short to avoid the memorization of the texts but to let learners get the general idea and rely on their creativity in the text reconstruction phase. It should not be too long either so that students can finish reconstruction and receive feedback in the same lesson. The speed and complexity of the input will have a significant effect on the learners' ability to process the text. As a general rule, the texts should be at or below the students' current proficiency level, although they may include some new vocabulary. These criteria were considered when selecting the texts for this study.

\section{Procedure}

As stated before, this study aimed at finding about the effectiveness of dictogloss on language learners' listening ability while focusing on their use of metacognitive listening strategies. In addition, it sought to determine whether gender could play a role. To this end, the study was conducted in the following manner.

First, in order to determine the participants' listening proficienc, the listening section of PET, as the pretest, was administered to both the experimental and control groups. It took them approximately 35 minutes to complete the test. Then, the MALQ was administered to the experimental group to determine their metacognitive listening strategy awareness before the treatment. Before implementing dictogloss to the experimental group, there was a short explanation about dictogloss and what learners were supposed to do in the course of 12 sessions they attended. The steps followed when using the dictogloss procedure are as follows.

Step 1: While the teacher read the text aloud once at a normal speed, the participants listened but did not write. The text was a story and included important words.

Step 2: The teacher read the text again at a normal speed and the participants took notes. They were expected to get the meaning of the text instead of writing down every word.

Step 3: The participants worked in separate groups to reconstruct the text in full sentences. The reconstructed text retained the meaning of the original text but was not necessarily a word-for-word copy of the text read by the teacher.

Step 4: Several groups read their reconstructed texts to the class and others listened and compared the text with their own reconstructed text. Each group's texts were collected by teacher, analyzed and returned to them. The control group was taught listening 
through the usual method of teaching listening. They performed a listening task in their book and answered some general questions.

After administering the treatment as outlined above, the posttest, the listening section of PET as well as the MALQ, were given to both the experimental and control groups. The collected data were then submitted to statistical tests to examine whether any significant changes in the learners' listening comprehension had occurred.

\section{RESULTS}

\section{Effect of Dictogloss on Listening Comprehension}

\section{Male students}

To answer the first question concerning the effect of dictogloss on listening comprehension as compared between male and female learners, within-group comparison was made between male and female students. Tables 1 and 2 present the results obtained from the performance of the male students.

According to Table 1, the mean value before the intervention was $14.77(\mathrm{M}=14.77, \mathrm{SD}=1.78)$; however, after administering the treatment, it was found to be 16.62 $(\mathrm{M}=16.62, \mathrm{SD}=.63)$, which represents a positive impact on students' listening comprehension.

Furthermore, as can be seen in Table 2, the performance of the male participants on the posttest outweighed that on the pretest, $t(12)=-5.19, p=0$. This means that the method was effective in improving the students' listening comprehension.

\section{Female students}

Tables 3 and 4 represent the results obtained from the effect of the dictogloss on the female students.

According to Table 3, the mean value before introducing the treatment was $14.84(\mathrm{M}=14.85, \mathrm{SD}=1.77)$ whereas after the intervention, this value changed to 16.15 $(\mathrm{SD}=2.47)$, which shows a positive impact on the students' listening comprehension. A paired samples t-test was then run to check the significance of the difference. According to Table 4, there was a significant difference between the performances of the experimental group before and after using the dictogloss technique, $t(12)=-3.04, p=0.01$. This indicates the effectiveness of dictogloss in improving female students' listening comprehension.

\section{Comparing male and female students'performances}

In order to examine whether the dictogloss technique had a significant impact on the listening comprehension of English language learners according to their gender, an independent samples t-test was run.

According to Table 5, the differences between male and female students turned out not to be statistically significant, $t(24)=0.49, p=0.62$. This indicates that gender was not a relevant issue as related to the effect of dictogloss on listening comprehension.
Table 1. Descriptive statistics for male students

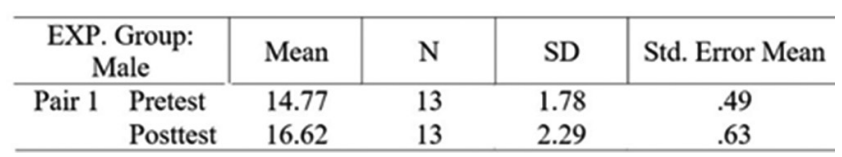

Table 2. Results of t-test for male students

\begin{tabular}{|c|c|c|c|c|c|c|c|c|}
\hline \multirow{3}{*}{$\begin{array}{l}\text { Experimental } \\
\text { Group: Male }\end{array}$} & \multicolumn{5}{|c|}{ Paired Differences } & \multirow{3}{*}{$\mathrm{t}$} & \multirow{3}{*}{ df } & \multirow{3}{*}{$\begin{array}{c}\text { Sig. } \\
\text { (2-tailed) }\end{array}$} \\
\hline & \multirow[t]{2}{*}{ M } & \multirow[t]{2}{*}{ SD } & \multirow{2}{*}{$\begin{array}{l}\text { Std. } \\
\text { Error } \\
\text { Mean }\end{array}$} & \multicolumn{2}{|c|}{$\begin{array}{c}95 \% \\
\text { Confidence } \\
\text { Interval of the } \\
\text { Difference } \\
\end{array}$} & & & \\
\hline & & & & Lower & Upper & & & \\
\hline $\begin{array}{l}\text { Pair } 1 \text { pretest- } \\
\text { posttest }\end{array}$ & -1.84 & 1.28 & .35 & -2.62 & -1.07 & -5.19 & 12 & .000 \\
\hline
\end{tabular}

Table 3. Descriptive statistics for female students

\begin{tabular}{|c|c|c|c|c|c|}
\hline \multicolumn{2}{|c|}{$\begin{array}{c}\text { Experimental } \\
\text { Group: Female }\end{array}$} & $\mathrm{M}$ & $\mathrm{N}$ & SD & $\begin{array}{l}\text { Std. Error } \\
\text { Mean }\end{array}$ \\
\hline & Pretest & 14.84 & 13 & 1.77 & .49 \\
\hline Pair 1 & Posttest & 16.15 & 13 & 2.47 & .68 \\
\hline
\end{tabular}

Table 4. Results of t-test for female students

\begin{tabular}{|c|c|c|c|c|c|c|c|c|}
\hline \multirow{3}{*}{$\begin{array}{l}\text { Experimental } \\
\text { Group: Female }\end{array}$} & \multicolumn{5}{|c|}{ Paired Differences } & \multirow{3}{*}{$t$} & \multirow{3}{*}{ df } & \multirow{3}{*}{$\begin{array}{c}\text { Sig. } \\
\text { (2-tailed) }\end{array}$} \\
\hline & \multirow[t]{2}{*}{ M } & \multirow{2}{*}{ SD } & \multirow{2}{*}{$\begin{array}{l}\text { Std. Error } \\
\text { Mean }\end{array}$} & \multicolumn{2}{|c|}{$\begin{array}{l}95 \% \text { Confidence } \\
\text { Interval of the } \\
\text { Difference }\end{array}$} & & & \\
\hline & & & & Lower & Upper & & & \\
\hline $\begin{array}{ll} & \text { pretest- } \\
\text { Pair } 1 & \text { posttest }\end{array}$ & -1.30 & 1.55 & .43 & -2.24 & -.37 & -3.04 & 12 & .010 \\
\hline
\end{tabular}

Table 5. Independent samples t-test for male and female participants

\begin{tabular}{|c|c|c|c|c|c|c|c|c|c|}
\hline & \multicolumn{2}{|c|}{$\begin{array}{l}\text { Levene's Test for } \\
\text { Equality of } \\
\text { Variances } \\
\end{array}$} & \multicolumn{7}{|c|}{ t-test for Equality of Means } \\
\hline & \multirow[b]{2}{*}{$\mathrm{F}$} & \multirow[b]{2}{*}{ Sig. } & \multirow[b]{2}{*}{$\mathrm{t}$} & \multirow[b]{2}{*}{ df } & \multirow{2}{*}{$\begin{array}{l}\text { Sig. (2- } \\
\text { tailed) }\end{array}$} & \multirow{2}{*}{$\begin{array}{c}\text { Mean } \\
\text { Difference }\end{array}$} & \multirow{2}{*}{$\begin{array}{l}\text { Std. Error } \\
\text { Difference }\end{array}$} & \multicolumn{2}{|c|}{$\begin{array}{c}95 \% \text { Confidence Interval of } \\
\text { the Difference }\end{array}$} \\
\hline & & & & & & & & Lower & Upper \\
\hline Equal variances assumed & .008 & .93 & .49 & 24 & .62 & .46 & .93 & -1.470 & 2.3940 \\
\hline $\begin{array}{l}\text { Equal variances not } \\
\text { assumed }\end{array}$ & & & .49 & 24 & .62 & .46 & .93 & -1.471 & 2.3946 \\
\hline
\end{tabular}

\section{Effect of Dictogloss on Students' Choice of Metacognitive Strategies}

To examine whether the dictogloss technique had any significant impact on the learners' choice of metacognitive strategies, the scores participants gained on the MALQ before and after the intervention were submitted to the paired-samples t-test. The analysis was done for male and female learners separately.

\section{Female students}

The mean scores of the female participants obtained from completing the MALQ, which demonstrate their use of metacognitive listening strategies before and after implementing the dictogloss technique were found to be $\mathrm{M}=88.30$ and 
$M=94.38$, respectively. According to Table 6 , the difference between the two mean scores was statistically significant, $t(12)=-5.15, p=0$.

Table 6. Results of paired samples t-test for choice of metacognitive strategies: Females

\begin{tabular}{|c|c|c|c|c|c|c|c|c|}
\hline & \multicolumn{5}{|c|}{ Paired Differences } & \multirow[b]{3}{*}{$t$} & \multirow[b]{3}{*}{ df } & \multirow{3}{*}{$\begin{array}{c}\text { Sig. } \\
\text { (2-tailed) }\end{array}$} \\
\hline & \multirow[b]{2}{*}{$\mathrm{M}$} & \multirow[b]{2}{*}{ SD } & \multirow{2}{*}{$\begin{array}{l}\text { Std. Error } \\
\text { Mean }\end{array}$} & \multicolumn{2}{|c|}{\begin{tabular}{|c|}
$\begin{array}{c}95 \% \text { Confidence } \\
\text { Interval of the } \\
\text { Difference }\end{array}$ \\
\end{tabular}} & & & \\
\hline & & & & Lower & Upper & & & \\
\hline $\begin{array}{rr}\text { Pair } 1 & \text { pretest- } \\
& \text { posttest }\end{array}$ & -6.07 & 4.25 & 1.17 & -8.64 & -3.50 & -5.15 & 12 & .000 \\
\hline
\end{tabular}

\section{Male students}

The same procedure as described above was followed for male students. A mean score of 85.84 ( $\mathrm{M}=85.84$, $\mathrm{SD}=31.55)$ from their responses to the MALQ after using the dictogloss technique as compared with a mean score of $80(\mathrm{M}=80, \mathrm{SD}=34.18)$ indicates improvement in the learners' use of metacognitive strategies. The results of statistical analysis presented in Table 7 shows that the difference between the participants' responses to the MALQ before and after the treatment was significant, $t(12)=-4.03, p=002$.

Table 7. Results of paired samples t-test for choice of metacognitive strategies: Males

\begin{tabular}{|c|c|c|c|c|c|c|c|c|c|}
\hline & & \multicolumn{5}{|c|}{ Paired Differences } & \multirow[b]{3}{*}{$\mathrm{t}$} & \multirow[b]{3}{*}{ df } & \multirow{3}{*}{$\begin{array}{c}\text { Sig. } \\
\text { (2-tailed) }\end{array}$} \\
\hline & & \multirow[b]{2}{*}{ M } & \multirow[b]{2}{*}{ SD } & \multirow{2}{*}{$\begin{array}{l}\text { Std. Error } \\
\text { Mean }\end{array}$} & \multicolumn{2}{|c|}{$\begin{array}{c}95 \% \text { Confidence } \\
\text { Interval of the } \\
\text { Difference } \\
\end{array}$} & & & \\
\hline & & & & & Lower & Upper & & & \\
\hline Pair 1 & $\begin{array}{l}\text { pretest - } \\
\text { posttest }\end{array}$ & -5.84 & 5.22 & 1.44 & -9.004 & -2.68 & -4.03 & 12 & .002 \\
\hline
\end{tabular}

\section{DISCUSSION}

This study sought to explore the effects of dictogloss on male and female EFL learners. Also, it aimed at find out whether dictogloss would influence the learners' use of metacognitive listening strategies. As the results demonstrated, dictogloss was effective as it assisted learners to improve their listening comprehension. However, there was not any significant difference in the gains of female learners as opposed to male students. The effectiveness of this technique can be attributed mainly to the way individual and group activities are combined. As explained by Thornton (1999), the reconstruction task, which takes place following taking notes by individual students while listening, gives students focus and a clear objective, which is a pre-condition for effective group work. Cooperative groups can develop more appropriate comparisons or examples that will aid learners in their comprehension. Noticing, which is one of the crucial elements of the language learning process (Ellis, 1995), occurs as a result of the reconstruction task, which encourages students to consider the input more closely. In other words, the nature of the reconstruction task requires students to listen carefully to other students' input, which provides more opportunities for listening practice (Prince, 2013; Vasiljevic, 2010).

Moreover, as opposed to the popular proposition that L2 learners often lack in top-down listening strategies, less-skilled listeners are often deficient in bottom-up processing skills (Tsui \& Fullilove, 1998). Dictogloss due to the nature of the reconstruction task which requires focused attention on the input helps develop bottom-up skills (Wilson, 2003).

The findings of this study lend further support to previous research on the role of dictogloss in improving listening comprehension. Badri, Badri and Nazari (2014) in their study of the effect of dictogloss reconstruction task on the learners' listening comprehension reported an increase in students' performance in listening comprehension. Similarly, Wahjuningsih (2011) examined the effectiveness of applying dictogloss within listening classes of male and female college students. The results showed dictogloss was quite effective in improving students listening comprehension. Using dictogloss with students in grade eleven of vocational schools, Widiasmara (2012) also reported improvement in students' listening ability. All in all, dictogloss appears to be encouraging in developing learners' listening comprehension.

\section{Dictogloss and Metacognitive Strategies}

The second question was concerned with how dictogloss would influence learners' use of metacognitive listening strategies. According to the results reported above, dictogloss proved to have a positive impact on both male and female learners' choice of metacognitive strategies. Learners' metacognitive awareness is related to effective learning in all learning contexts (Goh, 2002) and, specificall, in the context of L2 listening where these strategies have a direct and positive influence on listening performance (Goh \& Taib, 2006).

Considering the fact that there needs to be a shift of emphasis from product to process in listening practice and the responsibility of learning from the teacher to the students in order for them to become self-regulated learners (Vandergrift, 2002), it is then crucial to raise students' awareness of listening strategies through structured practice. As can be seen from the results of this study, dictogloss appears to be a promising technique in this regard. (Vandergrift, 1997; Walker, 2014).

The results of this study corroborate the findings of research on metacognitive instruction, which is believed to improve the listening comprehension ability of listeners. Although there are few studies which report non-significant changes in listening comprehension of learners as a result of metacognitive strategy instruction (e.g., Chen \& Haung, 2011; Seo, 2002), there is ample evidence that raising learners' awareness of metacognitive strategies will facilitate L2 listening. Yang (2009), for example, observed that one of the distinctive features differentiating successful listeners from unsuccessful ones is their use of metacognitive strategies, which helps them approach the listening task more effectively. Vandergrift (2007) also found a causal relationship between metacognitive instruction and statistically significant improvement in listening performance. 


\section{CONCLUSION}

The purpose of this study was to investigate the effect of dictogloss on Iranian EFL learners' listening comprehension with a focus on the role of gender and also its influence on learners' choice of metacognitive strategies. Findings indicate that the dictogloss technique can have a positive impact on the improvement of listening comprehension of EFL learners. It can also be claimed that dictogloss has a positive influence on the learners' choice of metacognitive strategies, which eventually improves learners' listening comprehension. The results, however, did not reveal a significant role for gender as related to the consequences of implementing dictogloss in teaching the listening skill.

\section{REFERENCES}

Alawiyah, T. \& Arrasyid, F. I. (2016). The effectiveness of dictogloss method on listening skill of narrative text at tenth grade students of Ma Al Iman Adiwerna Tegal. ELT-Echo, 1(1), 42-52.

Al-Alwan, A., Asassfeh, S. \& Al-Shboul, Y. (2013). EFL learners' listening comprehension and awareness of metacognitive strategies: how are they related? International Education Studies, 6(9), 31-36.

Badri, A., Badri, A., \& Nazari, J. (2014). The effects of task features (topic importance) on improving Iranian EFL learners' listening comprehension. International Journal of Educational Investigations, 1 (1), 111-121.

Berne, J. E. (2004). Listening comprehension strategies: A review of the literature. Foreign Language Annals, 37(4), 521-531.

Bozorgian, H. (2012). Metacognitive Instruction Does Improve Listening Comprehension. International Scholarly Research Network, 1-6.

Brown, G. (1995). Dimensions of difficulty in listening comprehension (59-73). In D. Mendelsohn \& J. Rubin(Eds.). San Diego, CA: Dominie Press.

Buck, G. (2001). Assessing listening. Cambridge: Cambridge University Press.

Byrnes. H. (1984). The role of listening comprehension: A Theoretical base. Foreign Language Annals, 17, 317329.

Caldwel, J. S. (2008). Comprehension assessment: A classroom guide. New York: Guilford Press.

Chamot, A. U. (1995). Learning strategies and listening comprehension. San Diego: Mendelson \& J. Rubin.

Chen, C. C. \& Huang, C. T. (2011). Raising EFL college students' metacognitive awareness about listening. Paper presented at the NYS TESOL $41^{\text {st }}$ Annual Conference, Melville, NY.

Chiu, B. E. (2006). An Investigation of English Listening Strategies Used by Continuous Education Program Students in Taiwan. Available at http://web.nanya.edu.tw/ tcof/tcrd/word.

Clement, J. (2007). The impact of teaching explicit listening strategies to adult intermediate-and advanced-level ESL university students. Retrieved from ProQuest Dissertations and Theses. (UMI No. 3253098).
Cross, J. (2010). Metacognitive instruction for helping lessskilled listeners. ELT Journal, 65(4), 408-416.

Coskun, A. (2010). The effect of metacognitive strategy training on the listening performance of beginner students. Novitas-ROYAL (Research on Youth and Language), 4(1), 35-50.

El-Esery, I. M. (2016). Dictogloss-based activities for developing EFL learners' listening comprehension. International Journal of English Language Teaching, 4(10), 42-51.

Field, J. (2008). Listening in the language classroom. Cambridge: Cambridge University Press.

Flowerdew, J., \& Miller, L. (2005). Second language listening: Theory and practice. New York: Cambridge University Press.

Goh, C. (2002). A cognitive perspective on language learners' listening comprehension problems. System, 28, 5575. http://dx.doi.org/10.1016/S0346-251X(99)00060-3.

Goh, C. (2008). Metacognitive instruction for second language listening development theory, practice and research implications. RELC Journal, 39(2), 188-213.

Goh, C., Taib, Y. (2006). Metacognitive instruction in listening for young learners. ELT Journal, 60(3), 222-32.

Habte-Gabr, E. (2006). The importance of socio-affective strategies in using EFL for teaching mainstream subjects. The Journal of Humanizing Language Teaching, $8(5), 1-5$.

Jibir-Daura, R. (2013). Using dictogloss as an interactive method of teaching listening comprehension. Advances in Language and Literary Studies, 4(2), 112-116.

Liu, Y. C. (2009). The utilization of listening strategies in the development of listening comprehension among skilled and less-skilled non-native English speakers at the college level. Retrieved from ProQuest Dissertations and Theses. (UMI No. 3400780).

Lu, P. H. (2008). English listening comprehension strategy used by students of pre-sessional courses of Northumbria University (Unpublished master thesis). Southern Taiwan University.

Macaro, E., Graham, S., \& Vanderplank, R. (2007). A review of listening strategies: Focus on sources of knowledge and on success. In A. Cohen, \& E. Macaro (Eds.), Language learner strategies: 30years of research and practice (pp. 165-185). Oxford: Oxford University Press.

Matheson, S., Moon, M., \& Winiecki, A. (2000). Improving student ability to follow directions through the use of listening skill instruction. Master's Action Research Project, Saint Xavier University \& SkyLight Professional Development. Retrieved from the ERIC database, ED 422148.

Mendelsohn, D. (1998). Teaching Listening. Annual Review of Applied Linguistics 18, pp. 81-101.

Mendelsohn, D. J., \& Rubin, J. (1995). A guide for the teaching of second language listening. San Diego, CA: Dominie Press.

Nunan, D. (1995). Language teaching Methodology: A textbookfor Teacher. Great Britain: Prentice Hall Europe.

Nunan, D. (2004). Task-based language teaching. Cambridge: Cambridge University Press. 
O’Malley, J. M., \& Chamot, A. U. (1990). Learning strategies in second language acquisition. Cambridge: Cambridge University Press.

Oxford, R. L. (1993). Research update on teaching L2 listening. System, 21(2), 205-211.

Prince, P. (2013). Listening, remembering, writing: Exploring the dictogloss task. Language Teaching Research, 17(4), 486-501.

Rahimi, M., \& Katal, M. (2012). Metacognitive listening strategies awareness in learning English as a foreign language: A comparison between university and highschool students. Procedia Social and Behavioural Sciences, 31, 82-89.

Rismayanti, W. (2009). Using dictogloss technique to improve students' listening ability. Indonesia: Unversitas Pendidikan. Retrieved on March 04, 2012 from: http:// repository.upi.edu/skripsiview.php?no_skripsi=833.

Rost, M. (2005). L2 listening. In: E. Hinkel (Ed.). Handbook of Research in Second Language teaching and Learning. ( $1^{\text {st }}$ ed.). Mahwah: Lawrence Earlbaum Associates, pp. 503-527.

Rost, M. (2011). Teaching and researching listening ( $2^{\text {nd }}$ ed.). Harlow: Longman.

Rubin, J. (1994). A review of second language listening comprehension research. The Modern Language Journal, 78(2), 199-221.

Seo, K. (2002). The effects of visuals on listening comprehension: A study of Japanese learners' listening strategies. International Journal of Listening, 16, 57-81.

Shak, J. (2006). Children using dictogloss to focus on form. Reflections on English Language eaching. 5(2), 47-62.

Thornton, P. (1999). Reading together. In D. Kluge, S. McGuire, D. Johnson, \& R. Johnson (Eds.). Cooperative learning (pp. 95-105). Japan: JALT Applied Materials.

Tsui, A.B. M., \& M. \& Fullilove, J. (1998). Bottom-up or top-down processing as a discriminator of L2 listening performance. Applied Linguistic, 19, 432-451.

Vandergrift, L., Goh, C., Mareschal, C., \& Tafaghodtari, M. H. (2006). The metacognitive awareness listening questionnaire (MALQ): Development and validation. Language Learning, 56(3), 431-462.

Vandergrift, L. (1997). The Cinderella of Communication Strategies: Receptive Strategies in Interactive Listening. Modern Language Journal, 81,494-505.

Vandergrift, L. (1999). Facilitating second language listening comprehension: Acquiring successful strategies. ELT Journal, 54, 168-176.
Vandergrift, L. (2004). Listening to learn or learning to listen? Annual Review of Applied Linguistics, 24, 3-25.

Vandergrift, L. (2005). Relationships among motivation orientations, metacognitive awareness and proficiency in L2 listening. Applied Linguistics, 26, 70-89.

Vandergrift, L. (2007). Recent developments in second and foreign language listening comprehension research. Language Teaching, 40(3), 191-210.

Vandergrift, L., \& Goh, C. (2011). Teaching a testing listening comprehension. In M. H. Long \& C. J. Doughty (Eds.), The handbook of language teaching (pp. 395411). USA: Blackwell Publishing Ltd.

Vandergrift, L., \& Tafaghodtari, M. H. (2010). Teaching L2 learners how to listen does make a difference: An empirical study. Language Learning, 60, 470-497. doi: 10.1111/j.1467-9922.2009.00559.x.

Vasiljevic, Z. (2010). Dictogloss as an interactive method of teaching listening comprehension to 12 learner. English Language Teaching, 3(1), 41-52. http://dx.doi. org/10.5539/elt.v3n1p41.

Wahjuningsih, E. (2011). The effect of applying dictogloss on students' listening comprehension at Faculty of Teacher Training and Education Jember University. Malang: Universitas Negeri.

Wajnryb, R. \& Malay, A. (1990). Grammar Dictation. Oxford: Oxford University Press.

Walker, N. (2014). Listening: The most difficult skill to teach. Encuentro, 23, 167-175.

Widdowson, H.G. 1983. Learning purpose and language use. Oxford: Oxford University Press.

Widiasmara, W. (2012). Teaching Listening Skill through Dictogloss Technique. Indonesia: Retrieved from http:// repository.upi.edu/skripsiview.php?no_skripsi=11169. Wilson, 2003.

Wilson, M. (2003). Discovery listening-improving perceptual processing. ELT Journal, 57(4), 335-343.

Yang, C. (2009). A study of metacognitive strategies employed by English listeners. International Education Studies. 2(4), 134-139.

Zeng, Y. 2007 'Metacognitive Instruction in Listening: A Study of Chinese Non-English Major Undergraduates' (Unpublished MA thesis, National Institute of Education, Nanyang Technological University, Singapore).

Zhang, W. \& Liu, M. (2008). Investigating cognitive and metacognitive strategy use during an English proficie cy test. Indonesian Journal of English Language Teaching, 4(2), 122-139. 